\title{
Social studies for awareness of toilet facilities in job to achieve environmental sanitation
}

\author{
Comfort Isuwa Jurmang \\ Department of Social Studies, Federal College of Education, Pankshin, Nigeria
}

\begin{abstract}
Social studies is a field of study concern with the study of people, places and environments. Ten children were randomly selected from five public primary schools in Jos to identify where people defecate through observations and interview. $100 \%$ of the respondents did not know what water closet and lavatory are. Water closet is locally referred to as water system toilet. $100 \%$ of them know toilet room, urinal, bathroom and pit latrines. Public institutions like Banks, Motor Parks, Fuel station and Public primary schools have different levels of provisions of toilets. Institutions that all have toilet facilities for the public are banks, and fuel stations. They observed that the toilets in banks are more kept neat than those at the fuel stations. The motor parks are worse in having toilet facilities. Only $20 \%$ ( 1) of the motor parks inspected have toilet facilities. The remaining $80 \%$ (4) did not have any toilet facilities. The $20 \%$ (1) motor parks that has toilet, is privately run so that users pay N10 for using the toilet. $20 \%$ (1) of the public schools have usable toilets. $80 \%$ (4) schools include those without toilets completely and those with but never usable at all.
\end{abstract}

Keywords: Social studies; environment; Public institutions; Banks, Motor Parks, Fuel station; Public primary schools

\section{INTRODUCTION}

Social studies is graphically presented as a college of forms, structures and colors. It has many aspects and dimensions. The subject integrates field of study from the various subjects that constitute the social sciences, the humanities and other subject areas such as the sciences (Bozimo 2008). According to Bruce (2009) social studies include the study of people, places and environments. It includes experiences that provide for the study of relationships among science, technology and society.

Meziobi (1992) stated that social studies is perceived as an integrated field of study with the focus on man and his interactions with his environments, intelligent, personal and societal problem solving and the production of functional citizenry. This is why Meziebi (1992) stated that social studies in Nigeria is a formalized correlated or integrated study of man and his environment which instills the learner with the cognition, skills, values, attitudes, abilities and competencies that will enable him become an informed, rational, analytical, participative and functional citizen (in his environments and beyond). Therefore social studies through environmental education can study environmental sanitation. 


\section{Environmental Education}

According to Wikipedia (2011) environmental education refers to organized efforts to teach how natural environments function and particularly how human beings can manage their behavior and ecosystems in order to live sustainably. The term is often used to imply education within the school system, from primary to post secondary. According to Okam and Ukachi (undated), the misuse and mismanagement of our environment in many ways have created the need for instituting environmental education within the framework of the Nigerian educational system. School must necessary participate in several planned and beneficial changes operating in her environment. Schools should be committed to environmental education. this can be achieved through schools fostering clear awareness of and concern about environmental issues; providing opportunities to acquire knowledge, values, attitudes, commitment and skills needed to protect and improve the environment and creating new patterns of behavior in individual groups and society as a whole towards the environment (Ivowi 1997). There is the need to promote environmental education and awareness amongst all strata of Nigerian society.

\section{Environmental Sanitation}

According to Berman (2011) poor water sanitation and a lack of safe drinking water takes a greater human toll than war, terrorism and weapons of mass destruction combined. Berman reveals that 4000 children die each day as a result of diseases caused by ingestion of filthy water. At any given time, close to half the population of the developing world suffers from waterborne diseases associated with inadequate provision of water and sanitation services. Berman further reveals that the four billion cases of diarrhea disease per year occur resulting in about one or two million deaths, some ninety percent of which tragically are in children under the age of five.

Cholera, typhoid fever and hepatitis A are caused by bacteria and are among the most common diarrheal diseases. Other illnesses such as dysentery are caused by parasites that live in water contaminated by the faeces of sick individuals. Lakes and streams which people use for drinking water, bathing and defecating are sources of disease. BBC hausa recently reported how members of a community in one of the states in Nigeria constructed latrines in their homes and got pipes run down from the latrines to the only source of water to the village and when they defecated they flushed to the source of water. This was an idea imported to the village by someone who went to the city and saw how pipes are used from toilets to suck away. It was when there was an outbreak of cholera and officials of the Ministry of Health came and discovered someone had wrongly reported the idea to them. Out of ignorance they did not know the health implication. People can also contract a diarrheal disease by eating food that is prepared by sick individuals who have not washed their hands or touched something handled by an infected person and then putting their own hands into their mouths. Sanitation is the hygienic means of promoting health through prevention of human contact with the hazards of waste. Hazards can be physical, microbiological, biological or chemical agents of disease. Waste that can cause health problems are human plus animal faeces, solid wastes, domestic wastewater (sewage), industrial wastes and agricultural wastes. Hygienic means of prevention can be by using engineering solutions (e.g. sewage and wastewater treatment). Simple technologies (e.g. latrines, septic tanks) or even by personal hygiene practices (e.g. simple hand washing with soap) (Wikipedia 2011).

WHO (2011) stated that sanitation generally refers to the provision of facilities and services for the safe disposal of human urine and faeces. It also refers to the maintenance of hygienic conditions through services such as garbage collection and waste water disposal. 
Sanitation can be in different forms. There is the basic sanitation. This refers to the management of human faeces at the household level. There is on site sanitation. This involves the collection and treatment of waste. There is food sanitation. It refers to hygienic measures for ensuring food safety. The popular one is the environmental sanitation. This is the control of environmental factors that form links in disease transmission. Environmental sanitation can be in the form of solid waste management, water and wastewater treatment, industrial waste treatment and noise pollution control.

\section{SANITATION IN JOS}

According to water Wiki (2011) an altitude survey on water supply and sanitation services carried out in Jos city showed that about $60 \%$ of the population that uses toilet uses the pour flush toilet system. This system consists of a squatting pan connected to double compartment septic tank via an S-trap and short pipe to a soakage pit. Most of the waste is digested in the septic tank while the effluent seeps into the surrounding soil in the soak away pit. The state Ministry of Environment and Housing and the Plateau State Environmental Protection and Sanitation (PEPSA) are authorities in charge of the strategies setting policies and reforms in the sanitation section. There was another agency, Plateau Rural Water Supply \&Sanitation Agency, Jos also responsible for sanitation. The current government has employed a number of women responsible for sweeping the streets of Jos. This has resulted to clean environment in quite a number of parts of the city. However, sustainability is the problem. There are times that the environment becomes filthy all over due to different reasons. There are instances of the workers being on strike, the people are stubborn and are bent on pouring the refuse anyhow. Sometimes threat of lack of security for the workers results in lack of cleaning the environment.

\section{DIFFERENT TYPES AND NAMES GIVEN TO TOILETS}

Toilets are facilities provided for human excretion often with accompanying hand washing facilities. It is advised that toilets should be clean, safe and well designed.

1. Water closet means a toilet facility maintained within a toilet room for the purpose of both defecation and urination and which is flushed with water.

2. Toilet room- a room maintained within or on the premises of any building, containing toilet facilities.

3. Urinal- a toilet facility maintained within a toilet room for the sole purpose of urination.

4. Toilet facility- a fixture maintained within a toilet room for the purpose of defecation, urination or both.

5. Restroom- a room equipped with toilets and lavatories for public use.

6. Lavatory- a room equipped with washing and often toilet facilities.

7. Bathroom- a room equipped with facilities for taking a bath or shower and usually also containing a sink and toilet. In this context "going to the bathroom" indicates the need to empty bowel or bladder.

8. A portable Sanitation Unit (PSU) portable chemical toilet for special events for which there are no permanent toilet facilities, PSUs should be provided in open crusade grounds.

9. Loo is another name for toilet. It is commonly used in the United Kingdom.

10. In most developing countries they use pit latrines. At one time bucket latrines were used. 
In some developing societies, people defecate and urinate in open spaces. No rooms are provided as toilets.

\section{CHOLERA OUTBREAK}

CNN (2011) reported the worst outbreak of cholera in Nigeria in the months of June and July 2011 which claimed the life of over 800 people in two months. The report states that five states affected include Plateau, Bauchi, Taraba, Adamawa and Kaduna. The epidemic spread to other states and neighbouring countries. The report further states that Plateau state was worst hit. The epidemic has been reported in six local government areas of the state. The local governments include; Barkin Ladi, Mangu, Pankshin, Shendam, Jos north and Jos north local governments. The epidemic was the worst in nearly two decades. It spread to neighbouring countries of Cameroon, Chad and Niger.

Families try to have clean environment by sweeping the rooms and the compounds. Women and girl children often wake up early and begin the day with sweeping. This is a habit observed by many families. A woman is judged by how clean her pots, dishes, her room and compound are. Unfortunately most villages in Plateau state have no tradition of providing toilets. There are vast bush lands and people go into the bush to defecate. During farming seasons, the crops grow tall and provide cover for people to defecate in the farms around the house. Those that are concerned with sanitation will carry a small hoe to the farm and after defecating; they will fetch a small amount of soil and cover the feces. This home background influences the attitude of people towards having knowledge and provision of toilets even when they come to live in the cities.

\section{1. Study on Provision of Toilet Facilities in Public Places}

A total of ten children were randomly selected from five public primary schools in Jos. They were asked to state the various types of toilet facilities they know. This simply means identifying where people defecate as they know. The children came out with the following:

1. Pit latrine

2. Water latrine

3. Bucket latrine

4. The use of bush

5. The use of polythene bags.

The ten children were exposed to the following names of toilet facilities and they embarked on using inquiry method in social studies to interview thirty people as to whether they know such terminologies, have seen them or used them:

1. Water closet

2. Toilet room

3. Urinal

4. Restroom

5. Lavatory

6. Bathroom

7. A portable Sanitation Unit (PSU)

8. Loo

9. Pit latrines.

10. Bucket latrines. 
Table 1. People's knowledge of terminologies that have to do with toilets.

\begin{tabular}{|cccc|}
\hline NAMIE OF FACILITY & $\%$ & $\%$ NO & TOTAL \\
Water closet & KNOWLEDGE & KNOWLEDGE & \\
Toilet room & $0 \%$ & $100 \%$ & $100 \%$ \\
Urinal & $100 \%$ & $0 \%$ & $100 \%$ \\
Restroom & $100 \%$ & $0 \%$ & $100 \%$ \\
Lavatory & $30 \%$ & $70 \%$ & $100 \%$ \\
Bathroom & $0 \%$ & $100 \%$ & $100 \%$ \\
A portable Sanitation Unit & $100 \%$ & $0 \%$ & $100 \%$ \\
(PSU) & $10 \%$ & $90 \%$ & $100 \%$ \\
Loo & $20 \%$ & $80 \%$ & $100 \%$ \\
Pit latrines. & $100 \%$ & $0 \%$ & $100 \%$ \\
Bucket latrines. & $30 \%$ & $70 \%$ & $100 \%$ \\
& & & \\
\hline
\end{tabular}

\section{DISCUSSION}

$100 \%$ of the respondents did not know what water closet and lavatory are. Water closet is locally referred to as water system toilet.

Things that people have $100 \%$ knowledge on include: Toilet room, Urinal, Bathroom, Pit latrines. These are common facilities used or people have seen in their life experience.

The ten randomly selected children from four primary schools visited a number of public places to find out whether they have toilet facilities for the public. The public include five each of:

1. Banks

2. Motor Parks

3. Fuel station

4. Public primary schools

Table 2. Public Institutions.

\begin{tabular}{cccc}
\hline INSTITUTION & $\begin{array}{c}\% \text { WITH } \\
\text { TOILET }\end{array}$ & $\begin{array}{c}\% \\
\text { WITHOUT } \\
\text { TOILET }\end{array}$ & TOTAL \\
BANKS & $100 \%(5)$ & $0 \%(0)$ & $100 \%(5)$ \\
MOTOR PARKS & $20 \%(1)$ & $80 \%(4)$ & $100 \%(5)$ \\
FUEL STATION & $100 \%(5)$ & $0 \%(0)$ & $100 \%(5)$ \\
PRIMARY SCHOOLS & $20 \%(1)$ & $480 \%(4)$ & $100 \%(5)$ \\
\hline
\end{tabular}


Institutions that all have toilet facilities for the public are banks, and fuel station. However the children observed that the toilets in banks are more kept neat than those at the fuel stations. The motor parks are worse in having toilet facilities. Only $20 \%$ (1) of the motor parks inspected by the children have toilet facilities. The remaining $80 \%(4)$ did not have any toilet facilities. In the case of the $20 \%$ (1) motor park that has toilet, it is being privately run so users pay N10 for using the toilet. Only $20 \%$ (1) of the public schools have usable toilets. The $80 \%$ (4) schools include those without toilets completely and those with but never usable at all. So it is better declaring them as having no toilets.

\section{CONCLUSION}

Many people are not aware of the different names and types of toilets since they are not exposed to the usage of toilets. Most often people use open space or easily walk to the bush to defecate. In the towns, people use polythene bags to defecate and later throw in the garbage. Some use the available space behind the house or gutters to defecate for lack of latrines. There is the need to expose people to different types of toilets of the world. This explains why despite all efforts in cleaning the environment, the state still faces health devastation in terms of cholera epidemic.

\section{References}

[1] Berman, J. (2011). Water borne diseasesis a world killer. WHO fact sheets on environment sanitation. http://www.int/water sanitation healthy hygiene/emergencies/envsanfactsheets/en/

[2] Bozimo, G.O. (2008). Efficiently in project/fund research activities for social studies teachers. New trends in primary school social studies pedagogy. Jos. Deka.

[3] Bruce, T. (2009) Curriculum Standards for Social Studies. http://www.socialstudies.org/standards/strands/

[4] CNN (2011) Cholera kills 1555 in Nigeria says UN. http://articles.cnn.com/2010-10-26/world/nigeria.cholera-outbreak-drinking-water-newcases?_s=pm. WORLD

[5] Mezieobi, K.A. (1992). Understanding social studies in Nigeria in Mezieobi k.A. Understanding social studies education in Nigeria Jos, Ishaku Printing press Ltd.

[6] Okam, C.C and Ukachi, (undated) Exploring environmental education for national development in Nigeria. A paper presented at the Faculty of Education University of Jos.

[7] Water Wiki (2011). Water borne diseases. http:www/en tech.com/library/diseases /waterbornediseases.htm

[8] WHO (2011). Fact sheets on environment sanitation http://www.int/water sanitation healthy hygiene/emergencies/envsanfactsheet/en.

[9] Wikipedia (2011). Sanitation. http://en.wikipedia.org/wiki/sanitation

[10] Tomáš Hes, Anna Poledňáková, International Letters of Social and Humanistic Sciences 2 (2013) 18-31.

[11] Mohsen Mehrara, Masoumeh zirak, International Letters of Social and Humanistic Sciences 2 (2013) 32-38.

[12] Taiwo Adewale Muritala, Ismail O. Fasanya, International Letters of Social and Humanistic Sciences 2 (2013) 39-50. 
[13] Borowski A., International Letters of Social and Humanistic Sciences 3 (2013) 46-53.

[14] Borowski A., International Letters of Social and Humanistic Sciences 3 (2013) 69-74.

[15] Donovan A. McFarlane, International Letters of Social and Humanistic Sciences 4 (2013) 35-44.

[16] Rajesh K. Yadav, Nishant Dabhade, International Letters of Social and Humanistic Sciences 4 (2013) 49-69.

[17] Borowski A., International Letters of Social and Humanistic Sciences 4 (2013) 70-74.

[18] Paul Bukuluki, International Letters of Social and Humanistic Sciences 5 (2013) 27-44.

[19] Mohsen Mehrara, Maysam Musai, International Letters of Social and Humanistic Sciences 5 (2013) 55-62.

[20] Debiprasad Mukherjee, International Letters of Social and Humanistic Sciences 6 (2013) 41-48.

[21] Tomáš Hes, Alena Neradová, Karel Srnec, International Letters of Social and Humanistic Sciences 7 (2013) 55-75.

[22] Kinga Dziwańska, International Letters of Social and Humanistic Sciences 7 (2013) 96-112.

[23] Borowski A., International Letters of Social and Humanistic Sciences 7 (2013) 113-118.

[24] Mohsen Mehrara, Maysam Musai, International Letters of Social and Humanistic Sciences 8 (2013) 1-7.

[25] Tittenbrun J., International Letters of Social and Humanistic Sciences 11 (2013) 10-34.

[26] Mohsen Mehrara, Hamid Abrishami, Mostafa Boroujli, Mahan Amin, International Letters of Social and Humanistic Sciences 11 (2013) 76-83.

[27] Borowski A., International Letters of Social and Humanistic Sciences 11 (2013) 100-105.

[28] Morteza Amani, Mahmood Goodarzi, Hamze Ahamadian, International Letters of Social and Humanistic Sciences 1 (2014) 7-13.

[29] Seyed Mohammad Marandi, Hossein Pirnajmuddin, International Letters of Social and Humanistic Sciences 1 (2014) 14-27.

[30] Elias Olukorede Wahab, Chioma Joan Ikebudu, International Letters of Social and Humanistic Sciences 1 (2014) 28-42.

[31] Bahram Meihami, Zeinab Varmaghani, Hussein Meihami, International Letters of Social and Humanistic Sciences 1 (2014) 43-5.

[32] Francis Briggs, Elizabeth Desmond, International Letters of Social and Humanistic Sciences 1 (2014) 71-80.

[33] Liverpool E. Onyije, Jacinta A. Opara, International Letters of Social and Humanistic Sciences 1 (2014) 81-87

[34] Sele Sylvester Ebisin, International Letters of Social and Humanistic Sciences 2 (2014) $1-9$.

[35] Tittenbrun J., International Letters of Social and Humanistic Sciences 2 (2014) 20-40.

[36] Borowski A., International Letters of Social and Humanistic Sciences 2 (2014) 110-121.

[37] Pawa Tersoo, International Letters of Social and Humanistic Sciences 3 (2014) 26-36.

[38] Rabi'u Muhammad Ishaq, International Letters of Social and Humanistic Sciences 3 (2014) 37-44.

[39] Adoga James Ada, International Letters of Social and Humanistic Sciences 3 (2014) 45-52.

[40] Bahram Meihami, Hussein Meihami, International Letters of Social and Humanistic Sciences 3 (2014) 80-91. 
[41] Kabiru Ibrahim Yankuzo, International Letters of Social and Humanistic Sciences 4 (2014) 1-8.

[42] Onyike Maggaret Odu, International Letters of Social and Humanistic Sciences 4 (2014) 31-39.

[43] Uloma Charity Oguzor, International Letters of Social and Humanistic Sciences 4 (2014) 97-104.

[44] Okezie A. Ihugba, Alex Odii, A. C. Njoku, International Letters of Social and Humanistic Sciences 5 (2014) 21-34.

[45] Okezie A. Ihugba, Bankoli Bankong, N. C. Ebomuche, International Letters of Social and Humanistic Sciences 5 (2014) 92-113.

[46] Borowski A., International Letters of Social and Humanistic Sciences 6 (2013) 86-90.

[47] Borowski A., International Letters of Social and Humanistic Sciences 3 (2013) 69-74. 